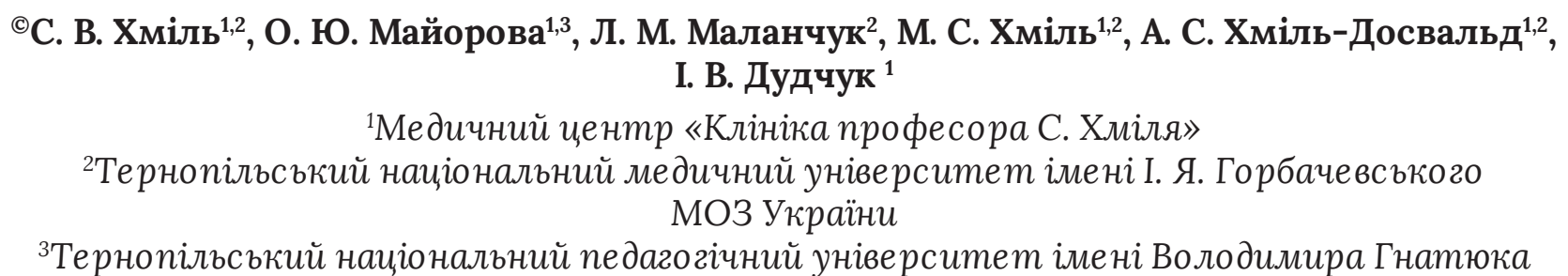

\title{
ФРАГМЕНТАЦІЯ ДНК СПЕРМАТОЗОЇДІВ: ПРИЧИНИ, МЕХАНІЗМ, ВПЛИВ НА НАСТАННЯ ТА ВИНОШУВАННЯ ВАГІТНОСТІ
}

Мета дослідження - вивчити причини фррагментації ДНК сперматозоїдів, встановити взаємозв'язок між порушенням ДНК та якістю еякуляту, а також вивчити вплив фррагментації ДНК сперматозоїдів на настання та виношування вагітності.

Матеріали та методи. У дослідженні використано бібліосемантичний та аналітичний методи.

Результати дослідження та їх обговорення. Під час виконання дослідження було проаналізовано 46 джерел сучасної зарубіжної літератури щодо фррагментації ДнК сперматозоїдів та її впливу на настання і виношування вагітності.

Висновки. Аналіз літературних даних показав, що рівень фрагментації ДНК сперматозоїдів у межах 15-30 \% є статистично значущим щодо зменшення позитивних результатів вагітності для in vivo, BMI, а також щодо підвищення ризику ранніх спонтанних викиднів. Якщо рівень фррагментації ДНК сперматозоїдів партнера >30 \%, найефективнішим методом допоміжних репродуктивних технологій буде IVF або ICSI. Проте потрібно пам'ятати про ризик виникнення вад розвитку у плода, пов'язаних із цими процедурами допоміжної репродукції. Визначення рівня сррагментації ДНК можна використовувати як корисний аналіз у прогнозуванні викиднів, спричинених чоловічим фактором.

Ключові слова: еякулят; фррагментація ДНК сперматозоїдів; допоміжні репродуктивні технології; виношування вагітності.

ФРАГМЕНТАЦИЯ ДНК СПЕРМАТОЗОИДОВ: ПРИЧИНЫ, МЕХАНИЗМ, ВЛИЯНИЕ НА НАСТУПЛЕНИЕ И ВЫНАШИВАНИЕ БЕРЕМЕННОСТИ

Цель исследования - изучить причины фррагментации ДНК сперматозоидов, установить взаимосвязь между нарушением ДНК и качеством эякулята, а также изучить влияние фрагментации ДНК сперматозоидов на наступление и вынашивание беременности.

Материалы и методы. В исследовании использованы библиосемантический и аналитический методы.

Результаты исследования и их обсуждение. Во время выполнения исследования было проанализировано 46 источников современной зарубежной литературы о фрагментации ДНК сперматозоидов и ее влиянии на наступление и вынашивание беременности.

Выводы. Анализ литературных данных показал, что уровень фррагментации ДНК сперматозоидов в пределах 15-30 \% является статистически значимым к уменьшению положительных исходов беременности in vivo, ВМИ, а также к повышению риска ранних спонтанных выкидышей. Если уровень фрагментации ДНК сперматозоидов партнера >30 \%, наиболее эфрфективным методом вспомогательных репродуктивных технологий будет IVF или ICSI. Но в то же время нужно помнить о риске возникновения пороков развития у плода, связанных с этими процедурами вспомогательной репродукции. Определение уровня фрагментации ДНК можно использовать как полезный анализ в прогнозировании выкидышей, вызванных мужским фрактором.

Ключевые слова: эякулят; фррагментация ДНК сперматозоидов; вспомогательные репродуктивные технологии; вынашивание беременности.

SPERM DNA FRAGMENTATION: CAUSES, MECHANISM, INFLUENCE ON THE ONSET AND CARRYING A PREGNANCY

The aim of the study - to investigate the causes of sperm DNA fragmentation, to establish the relationship between DNA disruption and ejaculate quality, and to study the effect of sperm DNA fragmentation on the onset and carrying a pregnancy.

Materials and Methods. Bibliosemantic and analytical methods were used in the research.

Results and Discussion. During the study, 46 sources of modern foreign literature on sperm DNA fragmentation and its impact on the onset and delivery of pregnancy were analyzed.

Conclusions. Analysis of the literature showed that the level of sperm DNA fragmentation in the range of $15-30 \%$ is statistically significant in terms of reducing positive pregnancy outcomes for in vivo, AMI, as well as in terms of increasing the risk of early miscarriage. If the level of DNA fragmentation of the partner's sperm is $>30 \%$, IVF or ICSI will be the most effective methods of assisted reproductive technologies. However, the risk of developing fetal malformations associated with these assisted reproduction procedures should be borne in mind. Determining the level of DNA fragmentation can be used as a useful analysis in predicting miscarriages caused by male factor.

Key words: ejaculate; sperm DNA fragmentation; assisted reproductive technologies; pregnancy. 
ВСТУП. На сьогодні у більшості репродуктологічних клінік для визначення чоловічої фертильності проводиться аналіз якісних і кількісних параметрів еякуляту (спермограма). Проте цього не достатньо для підтвердження і встановлення діагнозу чоловічого безпліддя.

По-перше, результати спермограми не завжди дають змогу встановити остаточний діагноз, оскільки приблизно в $15 \%$ чоловіків із безпліддям морфоорункціональні показники сперми у межах норми [1].

По-друге, жоден із рекомендованих Всесвітньою організацією охорони здоров'я (ВОО3) параметрів еякуляту (об'єм сперми, концентрація, рухливість та морфологія сперматозоїдів) не може дати прогноз частоти утворення бластоцист та імплантації ембріонів [2].

По-третє, у більшості пар із невстановленою формою безпліддя можуть спостерігатися проблеми чоловічого чинника фрертильності, спричинені високим рівнем фррагментації ДНК сперматозоїдів, що й визначає план подальшого лікування [3].

По-четверте, вченими доведено, що рівень фррагментації ДНК вищий в еякульованих сперматозоїдах порівняно зі сперматозоїдами з яєчок. Це підтверджує гіпотезу про те, що більша частина пошкоджень ДНК відбувається у сперматозоїдах переважно на посттестикулярному рівні $[4,5]$.

Мета дослідження - вивчити причини фррагментації ДНК сперматозоїдів, встановити взаємозв'язок між порушенням ДНК та якістю еякуляту, а також вивчити вплив фррагментації ДНК сперматозоїдів на настання та виношування вагітності.

МАТЕРІАЛИ ТА МЕТОДИ. У дослідженні використано бібліосемантичний та аналітичний методи.

РЕЗУЛЬТАТИ ДОСЛІДЖЕННЯ ТА ЇХ ОБГОВОРЕННЯ.

Серед основних причин фррагментації ДНК виділяють такі:

- фрізичні агенти (іонізуюче випромінювання, високі температури, атмосферозабруднюючі речовини);

- хімічні агенти (пестициди, хімічні речовини, протиракові препарати, деякі ліки, що відпускаються за рецептом, статеві інфекції);

- біологічні фрактори (вік, підвищений індекс маси тіла) $[6,7]$;

- стиль життя (куріння, вживання алкоголю, профеесійні впливи) [8-10];

- патологічні стани (лейкоцитоспермія, варикоцеле, онкологічні захворювання, крипторхізм, рак, лихоманка, вік, інфрекція) [11-14];

- ятрогенні (кріоконсервація сперми) [4].

Наприклад, Rubes J. зі співробітниками (2005) провели дослідження впливу забруднення повітря, що виникає внаслідок згоряння вугілля для промисловості та опалення будинків у Чехії. Вони встановили, що забруднення повітря призводить до пошкодження ДНК сперматозоїдів і тим самим збільшує частоту чоловічого опосередкованого безпліддя, викиднів та інших несприятливих наслідків виношування вагітності. Разом з тим не відмічено порушення інших показників еякуляту.

Дослідження взаємозв'язку між віком чоловіка та рівнем фрагментації ДНК сперматозоїдів показало, що вік має найсильніший вплив на цілісність ДНК сперматозоїдів. Здоровий 20-річний чоловік зазвичай має рівень фррагментації ДНК близько 5 \%. У 50-річних чоловіків рівень фррагментації коливається в межах 5-73 \%. У чоло- віків 20-30 років рідше спостерігали аномальні значення фррагментації, які спричинені анамнезом або чинниками навколишнього середовища [15].

Результатами багатьох останніх досліджень підтверджується взаємозв'язок між погіршенням характеристик сперми та збільшенням частки сперматозоїдів із фррагментацією ДНК [16-18]. Значну негативну кореляцію спостерігали між фррагментацією ДНК та концентрацією сперми $(r= \pm 0,44, p<0,01)$; між фррагментацією та рухливістю сперми ( $r= \pm 0,28, p<0,05)$, між фррагментацією та відсотком атипових фрорм $(r= \pm 0,36, p<0,01)$ [19].

Механізми виникнення ДНК фрагментації. На сьогодні ще не до кінця вивчені молекулярні механізми, які спричинюють фррагментацію ДНК. Але більшість вчених підтримують три теорії таких змін: десректи ремоделювання ДНК, апоптоз і оксидативні процеси [17, 20, 21].

У ході ремоделінгу хроматину, що відбувається за участю топоізомераз, виникають її одно- і дволанцюгові розриви, які характерні, головним чином, для постмейотичного дозрівання в ході сперматогенезу. Початок конденсації хроматину супроводжується збільшенням числа розривів ДНК, які репаруються за участю транзиторних білків [21, 22]. У процесі епідидимального транспорту сперматозоїдів цистеїнові групи протамінів, окиснюючись, утворюють дисульсрідні зв'язки, які стабілізують і компактизують хроматин. Процес компактизації хроматину відіграє важливу роль у формуванні головки сперматозоїда, інактивації транскрипції чоловічого генома, захисту і стабілізації ДНК сперматозоїдів [23]. Тому, нерепаровані розриви ДНК, що виникають у ході ремоделювання хроматину, розглядають як одне з головних джерел розривів ДНК у сперматозоїдах. Їх наявність свідчить про те, що процес дозрівання гамети завершився не належним чином.

Присутність розривів у ДНК може відображати і вираження апоптозу - генетично запрограмованої клітинної смерті. В ході сперматогенезу елімінація статевих клітин з різними порушеннями шляхом апоптозу є нормальним процесом. У нормі процес апоптозу запускається в 75 \% сперматогоніїв [24]. Загиблі в результаті цього клітини або фрагоцитуються клітинами Сертолі, або виходять у просвіт сім'яних канальців. При порушенні сперматогенезу зростає число статевих клітин, що вступають в апоптоз. Таким чином, розриви ДНК, які виявляються в еякульованих сперматозоїдах, можуть бути як наслідком десектів дозрівання в ході сперматогенезу (репарація і ремоделінг хроматину), так і маркерами, фракторами запуску апоптозу.

Ще однією причиною фррагментації ДНК сперматозоїдів є оксидативний стрес, який є процесом пошкодження клітин у результаті надлишкового рівня вільних радикалів [25]. Водночас, активні форми кисню є основними компонентами, що беруть участь у порушенні окисно-відновного стану клітини. Мішенню активних фрорм кисню $€$ ДНК сперматозоїдів. Поява внаслідок окиснення модифікованих основ ДНК, дестабілізує структуру макромолекули, що призводить до її розриву [26]. Оскільки сперматозоїди є дуже спеціалізованими клітинами з мінімальною кількістю цитоплазми, позаклітинний антиоксидантний захист є основним під час дозрівання сперматозоїдів в придатку яєчка. Зниження рівня антиоксидантів у секретах статевих шляхів призводить до оксидативного стресу і збільшення частоти фррагментації ДНК сперматозоїдів. 
Вплив фрагментації ДНК на настання та виношування вагітності. Важливим компонентом дослідження $€$ аналіз взаємозалежності рівня фррагментації ДНК сперматозоїдів із настанням вагітності природним шляхом, а також ефрективністю застосування допоміжних репродуктивних технологій (ДРТ).

Дослідження, проведені Evenson D. та Wixon R. (2006), показали, що настання вагітності in vivo було у 6,5 раза більше при рівні фррагментації ДНК $\leq 30 \%$. Spano M. зі співавт. (2000) наводять дещо відмінні результати: настання вагітності природним шляхом у жінок спостерігали у 10 разів частіше при умові, що рівень фррагментації ДНК сперматозоїдів партнера не перевищував $40 \%$.

Дані щодо впливу фрагментації ДНК на успішний результат під час використання внутрішньоматкової ін'єкції сперматозоїдів (ВМI) істотно відрізняються у різних авторів та у різні роки дослідження:

- Duran E. Н. зі співавт. (2002) не виявили вагітності при рівні фррагментації >12\%;

- Benchaib М. та ін. (2003) відзначили значне зменшення частоти вагітності при порозі $>20 \%$;

- Bungum М. зі співавт. (2004) відзначають збільшення частоти позитивних результатів зачаття та виношування дитини в 8,7 раза при сррагментації ДНК $\leq 27 \%$;

- Henkel R. зі співавт. $(2003,2004)$ вказують на значне зменшення позитивних результатів при рівні пошкодження ДНК сперматозоїдів >36,5 \%.

У програмі ICSI для порогового значення вище $10 \%$ виявлено значну негативну залежність між фррагментацією ДНК сперматозоїдів та швидкістю запліднення [31, 33]. Швидкість запліднення $€$ значно вищою при фррагментації ДНК нижче 10 \% і становить 84,1 \%, тоді як при фррагментації 15-20 \% - лише 70,7 \% [19].

Можливо, якщо фррагментація ДНК сперматозоїдів низька, ооцити здатні відновлювати пошкоджену ДНК сперматозоїдів [34, 35], що неможливо у випадках високого рівня фррагментації ДНК. Sakkas D. зі співавт. (1996) постулювали, що пошкоджена ДНК сперматозоїдів може сприяти зриву деконденсації ДНК сперматозоїдів після ICSI, що призводить до порушення запліднення. 3 іншого боку, Host E. та ін. (2000) припускали, що в ICSI ембріолог намагається відібрати рухомий i, наскільки це можливо, морфологічно нормальний сперматозоїд, тому ця клітина має кращі шанси також мати інтактну ДНК. Втім, сперматозоїд можна вважати «нормальним» і в той же час він може мати пошкоджену ДНК [36].

Ahmadi A. та Ng S. C. (1999b) показали, що висока фррагментація ДНК сперматозоїдів не погіршує запліднення, але перешкоджає утворенню бластоцист: при фррагментації не вище 4 \% вагітність наставала у $23 \%$ випадків; при фррагментації 15-18 \% частка вагітностей становила 10-15 \%; при фррагментації вище $20 \%$ не було жодної вагітності [19].

Henkel R. зі співавт. (2003), досліджуючи вплив рівня фррагментації ДНК сперматозоїдів на успішність використання IVF методу, відзначають настання вагітності жінок у 2 рази частіше у випадках фррагментації ДНК сперматозоїдів партнера $\leq 36,5 \%$. При рівні фррагментації ДНК сперматозоїдів <30 \% у звичайних пацієнтів із використанням IVF було вдвічі більше шансів на успішне виношування та народження дитини [38].
Тобто, високий рівень фррагментації ДНК сперматозоїдів має більш негативний вплив у циклах ICSI, але не $\epsilon$ значущим у циклах IVF, що узгоджується з результатами досліджень інших авторів [19, 39]. Цю різницю можна пояснити таким чином:

- більшість циклів ICSI проводять через погані характеристики сперми. При низькій якості сперми (за класичними критеріями) пошкодження ДНК виявляють на високому рівні [16-18], тому і більша вірогідність використання сперматозоїдів із підвищеною фррагментацією ДНК;

- вибір сперматозоїда, який будуть вводити, здійснюється за дуже грубими критеріями, а в разі поганих характеристик сперми неможливо вибрати навіть один морфологічно нормальний рухомий сперматозоїд, тому ризик ввести сперматозоїд із порушеною ДНК високий.

На відміну від ICSI, цикл IVF приводить до «природного» відбору сперматозоїдів: відібраний запліднюючий сперматозоїд буде морфологічно нормальним, активно рухливим і повинен мати непошкоджену ДНК [40]. Цю гіпотезу підтверджують останні дослідження, включаючи дослідження Van Dyk Q. зі співавт. (2000), які припускали, що людська zona pellucida має здатність до селекції проти анеуплоїдної сперми.

На сьогодні є лише невелика кількість досліджень впливу високого рівня фррагментації ДНК на виношування вагітності під час застосування ДРТ, однак їх результати такі.

Zini A. зі співавт. (2008) встановили, що, незалежно від типу ДРТ (IVF або ICSI), високий рівень пошкодження ДНК сперматозоїдів був прогностичним фрактором переривання вагітності після ДРТ.

Robinson L. та iн. (2012) повідомили, що використання під час IVF або ICSI сперми із високим рівнем пошкодження ДНК спричинювало більший у 2,16 раза ризик ранньої втрати вагітності.

Carrell D. T. зі співавт. (2003) припустили, що високий рівень фррагментації ДНК сперматозоїдів у чоловіків спричинює періодичні викидні (близько $35 \%$ ) у їх дружин, що $€$ значно вищим показником порівняно з середнім значенням у світі (22 \%) та нормальними фертильними чоловіками (12\%).

Check J. N. та ін. (2005) провели дослідження 106 чоловіків у парах, які звернулися до них із проблемою виношування вагітності (у минулому були викидні). Вчені встановили, що рівень фррагментації ДНК 30 \% і вище взаємопов'язаний із високим рівнем переривання вагітності на ранніх термінах.

Khadem N. та iн. (2014) також встановили позитивну кореляцію між викиднями у дружини і високим рівнем пошкодження ДНК сперматозоїдів у партнера.

Найбільш фундаментальним, важливим, простим та легким методом покращення якісних показників сперми чоловіків є зміна способу життя: відмова від алкоголю та куріння, уникання середовищ із високою температурою (сауни, робочі приміщення з підвищеною температурою), контроль маси тіла, здоровий спосіб життя (спорт, свіже повітря), носіння вільної нижньої білизни, зменшення стресового навантаження.

ВИСновКИ. Аналіз літературних даних показав, що рівень фррагментації ДНК сперматозоїдів у межах 15-30 \% $€$ статистично значущим щодо зменшення позитивних результатів вагітності для in vivo, BMI, а також щодо 
підвищення ризику ранніх спонтанних викиднів. Якщо рівень фррагментації ДНК сперматозоїдів партнера >30 \%, найефективнішим методом буде IVF або ICSI, однак потрібно пам'ятати про ризик виникнення вад розвитку у плода, пов'язаних із цими процедурами допоміжної репродукції. Визначення рівня фррагментації ДНК можна використовувати як корисний аналіз у прогнозуванні викиднів, спричинених батьківськими фракторами.

\section{СПИСОК ЛІТЕРАТУРИ}

1. Sperm morphology, motility, and concentration in fertile and infertile men / D. S. Guzick, J. W. Overstreet, P. Factor-Litvak [et al.] // New Engl. J. Med. - 2001. - Vol. 345 (19). - P. 1388-1393.

2. WHO. Laboratory manual for the examination of human semen and sperm-cervical mucus interaction (4th edn). Geneva: World Health Organization, Switzerland, 1999.

3. Sperm DNA integrity assessment in prediction of assisted reproduction technology outcome / M. Bungum, P. Humaidan, A. Axmon [et al.] // Hum. Reprod. - 2007. - Vol. 22 (1). - P. 174-179.

4. DNA damage in patients with untreated cancer as measured by the sperm chromatin structure assay / H. Kobayashi, K. Larson, R. K. Sharma [et al.] // Fertil. Steril. 2001. - Vol. 75 (3). - P. 469-475.

5. Efficient treatment of infertility due to sperm DNA damage by ICSI with testicular spermatozoa / E. Greco, F. Scarselli, M. lacobelli [et al.] // Hum. Reprod. - 2005. - Vol. 20 (1). - P. 226-230.

6. Pacey A. A. Environmental and lifestyle factors associated with sperm DNA damage / A. A. Pacey // Hum. Fertil. (Camb). - 2010. - Vol. 13 (4). - P. 189-193.

7. Kim G. Y. What should be done for men with sperm DNA fragmentation? / G. Y. Kim // Clin. Exp. Reprod. Med. - 2018. Vol. 45 (3). - P. 101-109.

8. Increased DNA damage in sperm from leukocytospermia semen samples as determined by the sperm chromatin structure assay / J. G. Alvarez, R. K. Sharma, M. Ollero [et al.] // Fertil. Steril. - 2002. - Vol. 78 (2). - P. 319-329.

9. Exposure to PCBs and p,p'-DDE and human sperm chromatin integrity / A. Rignell-Hydbom, L. Rylander, A. Giwercman [et al.] // Environ. Health Perspect. - 2002. Vol. 113 (2). - P. 175-179.

10. Episodic air pollution is associated with increased DNA fragmentation in human sperm without other changes in semen quality / J. Rubes, S. G. Selevan, D. P. Evenson [et al.] // Hum. Reprod. - 2005. - Vol. 20 (10). - P. 2776-2783.

11. Burrello N. Inhibition of oocyte fertilization by assisted reproductive techniques and increased sperm DNA fragmentation in the presence of Candida albicans: a case report / N. Burrello, A. E. Calogero, A. Perdichizzi // Reprod. Biomed. Online. - 2004. - Vol. 8 (5). - P. 569-573.

12. Effect of leukocytospermia on sperm DNA integrity: a negative effect in abnormal semen samples / J. Erenpreiss, S. Hlevicka, J. Zalkalns [et al.] // J. Androl. - 2002. - Vol. 23 (5). - P. 717-723.

13. Evenson D. P. Sperm chromatin structure assay: its clinical use for detecting sperm DNA fragmentation in male infertility and comparisons with other techniques / D. P. Evenson, K. L. Larson, L. K. Jost // J. Androl. - 2002. - Vol. 23 (1). - P. 25-43.

14. The impact of testicular carcinoma and its treatment on sperm DNA integrity / O. Stahl, J. Eberhard, K. Jepson [et al.] // Cancer. - 2004. - Vol. 100 (6). - P. 1137-1144.

15. Advancing male age increase the frequencies of sperm with DNA fragmentation and certain gene mutations, but not aneuploidies or diploidies / A. J. Wyrobek, B. Eskenazi, D. Evenson [et al.] // Proc. Natl. Acad. Sci. U. S. A. - 2006. Vol. 103 (25). - P. 9601-9606.

16. DNA integrity in human spermatozoa: relationships with semen quality / D. S. Irvine, J. P. Twigg, E. L. Gordon [et al.] // J. Androl. - 2000. - Vol. 21 (1). - P. 33-44.
17. Study of apoptotic DNA fragmentation in human spermatozoa / L. Gandini, F. Lombardo, D. Paoli [et al.] // Hum. Reprod. - 2000. - Vol. 15 (4). - P. 830-839.

18. Sperm swim-up techniques and DNA fragmentation / E.V. Younglai, D. Holt, P. Brown [et al.] // Hum. Reprod. - 2001. - Vol. 16 (9). - P. 1950-1953.

19. Sperm DNA fragmentation decreases the pregnancy rate in an assisted reproductive technique / M. Benchaib, V. Braun, J. Lornage [et al.] // Hum. Reprod. - 2003. - Vol. 18 (5). - P. 1023-1028.

20. Oxidative stress is associated with increased apoptosis leading to spermatozoa DNA damage in patients with male factor infertility / X. Wang, R. K. Sharma, S. C. Sikka [et al.] // Fertil. Steril. - 2003. - Vol. 80 (3). - P. 531-535.

21. Fuentes-Mascorro G. Sperm chromatin / G. FuentesMascorro, H. Serrano, A. Rosado // Arch. Androl. - 2000. Vol. 45 (3). - P. 215-225.

22. Boissonneault $G$. Chromatin remodeling during spermiogenesis: a possible role for the transition proteins in DNA strand break repair / G. Boissonneault // FEBS Lett. - 2002. Vol. 514 (2-3). - P. 111-114.

23. The role of histones in chromatin remodelling during mammalian spermiogenesis / J. Govin, C. Caron, C. Lestrat [et al.] // Eur. J. Biochem. - 2004. - Vol. 271 (17). - P. 3459-3469.

24. Expression of $\mathrm{Bcl}-2$ family proteins and spontaneous apoptosis in normal human testis / N. B. Oldereid, P. D. Angelis, R. Wiger [et al.] // Mol. Hum. Reprod. -2001. - Vol. 7 (5). - P. 403-408.

25. Live births after IVF in men with a DNA fragmentation index of $30 \%$ or greater as determined by the sperm chromatin structure assay (SCSA $\left.{ }^{\mathrm{TM}}\right)$ / F. Barnes, F. Rabara, A. Murphy, C. Zouves // Fertil. Steril. - 2004. - Vol. 82 (2). - P. S47.

26. Buyalos R. Poor fertility predictive value of the sperm chromatin structure assay (SCSA) is neutralized by sperm injection: case studies / R. Buyalos, G. Hubert, M. C. Schiewe // Fertil. Steril. - 2004. - Vol. 81 (3). - P. 27-28.

27. Evenson D. Meta-analysis of sperm DNA fragmentation using the sperm chromatin structure assay/D. Evenson, R. Wixon // Reprod. Biomed. Online. -2006. - Vol. 12 (4). - P. 466-472.

28. Sperm chromatin damage impairs human fertility $/$ M. Spano, J. Bonde, H. I. Hjollund [et al.] // Fertil. Steril. - 2000. - Vol. 73 (1). - P. 43-50.

29. Sperm DNA quality predicts intrauterine insemination outcome: a prospective cohort study / E. H. Duran, M. Morshedi, S. Taylor [et al.] // Hum. Reprod. - 2002. - Vol. 17 (12). P. 3122-3128.

30. The predictive value of sperm chromatin structure assay (SCSA $尺$ ) parameters for the outcome of intrauterine insemination, IVF and ICSI / M. Bungum, P. Humaidan, M. Spano [et al.] // Hum. Reprod. - 2004. - Vol. 19 (6). - P. 1401-1408.

31. DNA fragmentation of spermatozoa and assisted reproduction technology / R. Henkel, E. Kierspel, M. Hajimohammad [et al.] // Reprod. Biomed. Online. - 2003. - Vol. 7 (4). - P. 477-484.

32. Sperm deoxyribonucleic acid fragmentation is increased in poor-quality semen samples and correlates with failed fertilization in intracytoplasmic sperm injection / S. Lopes, J. G. Sun, A. Jurisicova [et al.] // Fertil. Steril. - 1998. - Vol. 69 (3). - P. 528-532. 
33. Host E. The role of DNA strand breaks in human spermatozoa used for IVF and ICSI / E. Host, S. Lindenberg, S. Smidt-Jensen // Acta Obstet. Gynecol. Scand. - 2000. Vol. 79 (7). - P. 559-563.

34. Sperm chromatin anomalies can influence decondensation after intracytoplasmic sperm injection / D. Sakkas, F. Urner, P. G. Bianchi [etal.] // Hum. Reprod. -1996. - Vol. 11 (4). - P. 837-843.

35. Ahmadi A. Fertilizing ability of DNA-damaged spermatozoa / A. Ahmadi, S. C. Ng // J. Exp. Zool. - 1999. Vol. 284 (6). - P. 696-704.

36. Interrelationships between seminal parameters and sperm nuclear DNA damage before and after density gradient centrifugation: implications for assisted conception / M. J. Tomlinson, O. Moffatt, G. C. Manicardi [et al.] // Hum. Reprod. - 2001. - Vol. 16 (10). - P. 2160-2165.

37. Ahmadi A. Developmental capacity of damaged spermatozoa / A. Ahmadi, S. C. Ng // Hum. Reprod. - 1999. Vol. 14 (9). - P. 2279-2285.

38. Virro M. R. Sperm chromatin structure assay (SCSA®) related to blastocyst rate, pregnancy rate and spontaneous abortion in IVF and ICSI cycles / M. R. Virro, K. L. Larson-Cook, D. P. Evenson // Fertil. Steril. - 2004. - Vol. 81 (15). - P. 1289-1295.

39. Simon L. Review: diagnosis and impact of sperm DNA alterations in assisted reproduction / L. Simon, B. R. Emery, D. T. Carrell // Best Pract. Res. Clin. Obstet. Gynaecol. - 2017. - Vol. 44. - P. 38-56.

\section{REFERENCES}

1. Guzick, D.S., Overstreet, J.W., Factor-Litvak, P., Brazil, C.K., Nakajima, S.T., Coutifaris, C., ..., \& Vogel, D.L. (2001). Sperm morphology, motility, and concentration in fertile and infertile men. New Engl. J. Med., 345 (19), 1388-1393. DOI:10.1056/ NEJMoa003005.

2. WHO. (1999). Laboratory manual for the examination of human semen and sperm-cervical mucus interaction (4th edn.). Geneva: World Health Organization, Switzerland.

3. Bungum, M., Humaidan, P., Axmon, A., Spano, M., Bungum, L., Erenpreiss, J., \& Giwercman, A. (2007). Sperm DNA integrity assessment in prediction of assisted reproduction technology outcome. Hum. Reprod., 22 (1), 174-179. DOI:10.1093/humrep/del326.

4. Kobayashi, H., Larson, K., Sharma, R.K., Nelson, D.R., Evenson, D.P., Toma, H., ..., \& Agarwal, A. (2001). DNA damage in patients with untreated cancer as measured by the sperm chromatin structure assay. Fertil. Steril., 75 (3), 469-475. DOI:10.1016/s0015-0282(00)01740-4.

5. Greco, E., Scarselli, F., lacobelli, M., Rienzi, L., Ubaldi, F., Ferrero, S., ..., \& Tesarik, J. (2005). Efficient treatment of infertility due to sperm DNA damage by ICSI with testicular spermatozoa. Hum. Reprod., 20 (1), 226-230. DOI:10.1093/ humrep/deh590.

6. Pacey, A.A. (2010). Environmental and lifestyle factors associated with sperm DNA damage. Hum. Fertil. (Camb), 13 (4), 189-193. DOI:10.3109/14647273.2010.531883.

7. Kim, G.Y. (2018). What should be done for men with sperm DNA fragmentation? Clin. Exp. Reprod. Med., 45 (3), 101-109. DOI:10.5653/cerm.2018.45.3.101.

8.Alvarez, J.G., Sharma, R.K., Ollero, M., Saleh, R.A., Lopez,M.L., Thomas, A.J., ..., \& Agarwal, A. (2002). Increased DNA damage in sperm from leukocytospermia semen samples as determined by the sperm chromatin structure assay. Fertil. Steril., 78 (2), 319-329. DOI:10.1016/s0015-0282(02)03201-6.

9. Rignell-Hydbom, A., Rylander, L., Giwercman, A., Jönsson, B.A.G., Lindh, C., Eleuteri, P., ..., \& Hagmar, L. (2005). Exposure to PCBs and p,p'-DDE and human sperm
40. Tomsu M. Embryo quality and IVF treatment outcomes may correlate with different sperm comet assay parameters / M. Tomsu, V. Sharma, D. Miller // Hum. Reprod. - 2002. Vol. 17 (7). - P. 1856-1862.

41. Incidence of aneuploid spermatozoa from subfertile men: selected with motility versus hemizona bound / Q. Van Dyk, S. Lanzendorf, P. Kolm [et al.] // Hum. Reprod. - 2000. Vol. 15 (7). - P. 1529-1536.

42. Sperm DNA damage is associated with an increased risk of pregnancy loss after IVF and ICSI: systematic review and meta-analysis / A. Zini, J. M. Boman, E. Belzile [et al.] // Hum. Reprod. - 2008. - Vol. 23 (12). - P. 2663-2668.

43. The effect of sperm DNA fragmentation on miscarriage rates: a systematic review and meta-analysis / L. Robinson, I. D. Gallos, S. J. Conner [et al.] // Hum. Reprod. - 2012. Vol. 27 (10). - P. 2908-2917.

44. Sperm DNA fragmentation is increased in couples with unexplained recurrent pregnancy loss / D. T. Carrell, L. Liu, C. M. Peterson [et al.] // Arch. Androl. -2003. - Vol. 49 (1). - P. 49-55.

45. Effect of an abnormal sperm chromatin structural assay (SCSA) on pregnancy outcome following (IVF) with ICSI in previous IVF failures / J. H. Check, V. Graziano, R. Cohen [et al.] // Arch. Androl. - 2005. - Vol. 51 (2). - P. 121-214.

46. Sperm DNA fragmentation in couples with unexplained recurrent spontaneous abortions / N. Khadem, A. Poorhoseyni, M. Jalali [et al.] // Andrologia. - 2014. - Vol. 46 (2). - P. 126-130.

chromatin integrity. Environ. Health Perspect., 113 (2), 175-179. DOI:10.1289/ehp.7252.

10. Rubes, J., Selevan, S.G., Evenson, D.P., Zudova, D., Vozdova, M., Zudova, Z., ..., \& Perreault, S.D. (2005). Episodic air pollution is associated with increased DNA fragmentation in human sperm without other changes in semen quality. Hum. Reprod., 20 (10), 2776-2783. DOI:10.1093/humrep/dei122.

11. Burrello, N., Calogero, A.E., \& Perdichizzi, A. (2004). Inhibition of oocyte fertilization by assisted reproductive techniques and increased sperm DNA fragmentation in the presence of Candida albicans: a case report. Reprod. Biomed. Online, 8 (5), 569-573. DOI:10.1016/s1472-6483(10)61104-2.

12. Erenpreiss, J., Hlevicka, S., Zalkalns, J., \& Erenpreisa, J. (2002). Effect of leukocytospermia on sperm DNA integrity: a negative effect in abnormal semen samples. J. Androl., 23 (5), 717-723. DOI:10.1002/j.1939-4640.2002.tb02315.x.

13. Evenson, D.P., Larson, K.L., \& Jost, L.K. (2002). Sperm chromatin structure assay: its clinical use for detecting sperm DNA fragmentation in male infertility and comparisons with other techniques. J. Androl., 23 (1), 25-43.

14. Stahl, O., Eberhard, J., Jepson, K., Spano, M., Cwikiel, M., Cavallin-Ståhl, E., \& Giwercman A. (2004). The impact of testicular carcinoma and its treatment on sperm DNA integrity. Cancer, 100 (6), 1137-1144. DOI:10.1002/cncr.20068.

15. Wyrobek, A.J., Eskenazi, B., Evenson, D., Young, S., Arnheim, N., Jabs, E.W., ..., \& Tiemann-Boege, I. (2006). Advancing male age increase the frequencies of sperm with DNA fragmentation and certain gene mutations, but not aneuploidies or diploidies. Proc. Natl. Acad. Sci. U. S. A., 103 (25), 9601-9606.

16. Irvine, D.S., Twigg, J.P., Gordon, E.L., Fulton, N., Milne, P.A., \& Aitken, R.J. (2000). DNA integrity in human spermatozoa: relationships with semen quality. J. Androl., 21 (1), 33-44.

17. Gandini, L., Lombardo, F., Paoli, D., Caponecchia, L., Familiari, G., Verlengia, C., ..., \& Lenzi, A. (2000). Study of apoptotic DNA fragmentation in human spermatozoa. Hum. Reprod., 15 (4), 830-839. DOI:10.1093/humrep/15.4.830.

18. Younglai, E.V., Holt, D., Brown, P., Jurisicova, A., \& 
Casper, R.F. (2001). Sperm swim-up techniques and DNA fragmentation. Hum. Reprod., 16 (9), 1950-1953. DOI:10.1093/ humrep/16.9.1950.

19. Benchaib, M., Braun, V., Lornage, J., Hadj, S., Salle, B., Lejeune, H., \& Guérin, J.F. (2003). Sperm DNA fragmentation decreases the pregnancy rate in an assisted reproductive technique. Hum. Reprod., 18 (5), 1023-1028. DOI:10.1093/ humrep/deg228.

20. Wang, X., Sharma, R.K., Sikka, S.C., Thomas, A.J., Falcone, T., \& Agarwal, A. (2003). Oxidative stress is associated with increased apoptosis leading to spermatozoa DNA damage in patients with male factor infertility. Fertil. Steril., 80 (3), 531535. DOI:10.1016/s0015-0282(03)00756-8.

21. Fuentes-Mascorro, G., Serrano, H., \& Rosado, A (2000). Sperm chromatin. Arch. Androl., 45 (3), 215-225. DOI:10.1080/01485010050193995.

22. Boissonneault, G. (2002). Chromatin remodeling during spermiogenesis: a possible role for the transition proteins in DNA strand break repair. FEBS Lett., 514 (2-3), 111-114. DOI:10.1016/ S0014-5793(02)02380-3.

23. Govin, J., Caron, C., Lestrat, C., Rousseaux, S., \& Khochbin, S. (2004). The role of histones in chromatin remodelling during mammalian spermiogenesis. Eur. J. Biochem., 271 (17), 3459-3469. DOI:10.1111/j.1432-1033.2004.04266.x.

24. Oldereid, N.B., Angelis, P.D., Wiger, R., \& Clausen, O.P. (2001). Expression of $\mathrm{Bcl}-2$ family proteins and spontaneous apoptosis in normal human testis. Mol. Hum. Reprod., 7 (5), 403-408.

25. Barnes, F., Rabara, F., Murphy, A., \& Zouves, C. (2004). Live births after IVF in men with a DNA fragmentation index of $30 \%$ or greater as determined by the sperm chromatin structure assay (SCSA $\left.{ }^{\mathrm{TM}}\right)$. Fertil. Steril., 82 (2), S47.

26. Buyalos, R., Hubert, G., \& Schiewe, M.C. (2004). Poor fertility predictive value of the sperm chromatin structure assay (SCSA) is neutralized by sperm injection: case studies. Fertil. Steril., 81 (3), 27-28.

27. Evenson, D., \& Wixon, R. (2006). Meta-analysis of sperm DNA fragmentation using the sperm chromatin structure assay. Reprod. Biomed. Online, 12 (4), 466-472. DOI:10.1016/ s1472-6483(10)62000-7.

28. Spano, M., Bonde, J., Hjollund, H.I., Kolstad, H.A., Cordelli, E., \& Leter G. (2000). Sperm chromatin damage impairs human fertility. Fertil. Steril., 73 (1), 43-50. DOI:10.1016/ s0015-0282(99)00462-8.

29. Duran, E.H., Morshedi, M., Taylor, S., Oehninger, S. (2002). Sperm DNA quality predicts intrauterine insemination outcome: a prospective cohort study. Hum. Reprod., 17 (12), 3122-3128. DOI: 10.1093/humrep/17.12.3122.

30. Bungum, M., Humaidan, P., Spano, M., Jepson, K., Bungum, L., \& Giwercman, A. (2004). The predictive value of sperm chromatin structure assay (SCSA $₫$ ) parameters for the outcome of intrauterine insemination, IVF and ICSI. Hum. Reprod., 19 (6), 1401-1408. DOI:10.1093/humrep/deh280.

31. Henkel, R., Kierspel, E., Hajimohammad, M., Stalf, T., Hoogendijk, C., Mehnert, C., ..., \& Kruger, T.F. (2003). DNA fragmentation of spermatozoa and assisted reproduction technology. Reprod. Biomed. Online, 7 (4), 477-484. DOI:10.1016/ s1472-6483(10)61893-7.

32. Lopes, S., Sun, J.G., Jurisicova, A., Meriano, J., \& Casper, R.F. (1998). Sperm deoxyribonucleic acid fragmentation is increased in poor-quality semen samples and correlates with failed fertilization in intracytoplasmic sperm injection. Fertil. Steril., 69 (3), 528-532. DOI:10.1016/s0015-0282(97)00536-0.
33. Host, E., Lindenberg, S., \& Smidt-Jensen, S. (2000). The role of DNA strand breaks in human spermatozoa used for IVF and ICSI. Acta Obstet. Gynecol. Scand., 79 (7), 559-563.

34. Sakkas, D., Urner, F., Bianchi, P.G., Bizzaro, D., Wagner, I., Jaquenoud, N., ..., \& Campana, A. (1996). Sperm chromatin anomalies can influence decondensation after intracytoplasmic sperm injection. Hum. Reprod., 11 (4), 837-843. DOI:10.1093/ oxfordjournals.humrep.a019263.

35. Ahmadi, A., \& Ng, S.C. (1999). Fertilizing ability of DNA-damaged spermatozoa. J. Exp. Zool., 284 (6), 696-704. DOI:10.1002/(sici)1097-010x(19991101)284:6<696::aidjez11>3.0.co;2-e.

36. Tomlinson, M.J., Moffatt, O., Manicardi, G.C., Bizzaro, D., Afnan, M., \& Sakkas, D. (2001). Interrelationships between seminal parameters and sperm nuclear DNA damage before and after density gradient centrifugation: implications for assisted conception. Hum. Reprod., 16 (10), 2160-2165. DOI:10.1093/ humrep/16.10.2160.

37. Ahmadi, A., \& Ng, S.C. (1999). Developmental capacity of damaged spermatozoa. Hum. Reprod., 14 (9), 2279-2285. DOI:10.1093/humrep/14.9.2279.

38. Virro, M.R., Larson-Cook, K.L., \& Evenson, D.P. (2004). Sperm chromatin structure assay (SCSA $\AA$ ) related to blastocyst rate, pregnancy rate and spontaneous abortion in IVF and ICSI cycles. Fertil. Steril., 81 (15), 1289-1295. DOI:10.1016/j. fertnstert.2003.09.063.

39. Simon, L., Emery, B.R., \& Carrell, D.T. (2017). Review: diagnosis and impact of sperm DNA alterations in assisted reproduction. Best Pract. Res. Clin. Obstet. Gynaecol., 44, 3856. DOI:10.1016/j.bpobgyn.2017.07.003.

40. Tomsu, M., Sharma, V. \& Miller, D. (2002). Embryo quality and IVF treatment outcomes may correlate with different sperm comet assay parameters. Hum. Reprod., 17 (7), 1856-1862. DOI:10.1093/humrep/17.7.1856.

41. Van Dyk, Q., Lanzendorf, S., Kolm, P., Hodgen, D.J. \& Mahony, M.C. (2000). Incidence of aneuploid spermatozoa from subfertile men: selected with motility versus hemizona bound. Hum. Reprod., 15 (7), 1529-1536.

42. Zini, A., Boman, J.M., Belzile, E., \& Ciampi, A. (2008). Sperm DNA damage is associated with an increased risk of pregnancy loss after IVF and ICSI: systematic review and metaanalysis. Hum. Reprod., 23 (12), 2663-2668. DOI:10.1093/ humrep/den321.

43. Robinson, L., Gallos, I.D., Conner, S.J., Rajkhowa, M., Miller, D., Lewis, S., ..., \& Coomarasamy, A. (2012). The effect of sperm DNA fragmentation on miscarriage rates: a systematic review and meta-analysis. Hum. Reprod., 27 (10), 2908-2917. DOI:10.1093/humrep/des261.

44. Carrell, D.T., Liu, L., Peterson, C.M., Jones, K.P., Hatasaka, H.H., Erickson, L., \& Campbell, B. (2003). Sperm DNA fragmentation is increased in couples with unexplained recurrent pregnancy loss. Arch. Androl., 49 (1), 49-55. DOI:10.1080/01485010290099390.

45. Check, J.H., Graziano, V., Cohen, R., Krotec, J., \& Check, M.L. (2005). Effect of an abnormal sperm chromatin structural assay (SCSA) on pregnancy outcome following (IVF) with ICSI in previous IVF failures. Arch. Androl., 51 (2), 121-214. DOI:10.1080/014850190518125.

46. Khadem, N., Poorhoseyni, A., Jalali, M., Akbary, A., \& Heydari, S.T. (2014). Sperm DNA fragmentation in couples with unexplained recurrent spontaneous abortions. Andrologia, 46 (2), 126-130. DOI:10.1111/and.12056.

Отримано 29.09.20

Прийнято до друку 30.10.20

Електронна адреса для листування: malanchuk@tdmu.edu.ua 